\title{
Culture and Corruption: A Critical Analysis of the Basis of Nigerian Depraved Experience
}

\author{
Gregory Emeka Chinweuba \\ http://dx.doi./org/10.4314/ujah.v19i2.6
}

\begin{abstract}
Evidently, the spate of corruption in Nigeria is worrisome. This is as it has defied every leadership strategy, and has continued to eat deep into the fabric of Nigerian society. But how and why did corruption get into the Nigerian society? This paper analytically investigates the basis of corruption in Nigeria, and proffers some panacea to the prevalent corrupt practices stunting every sustainable development. The study however finds that corruption is dependent on some cultural elements which enkindle and abet it. It again discovers that since culture is the matrix of human existence and nothing happens outside it, human corrupt practices stem from cultural systems. This is more so as corrupt practices are also understood and interpreted within cultural space. The paper concludes that corruption can be retrogressed when there is a positive review of those unwholesome cultural elements prevalent in diverse cultures of Nigeria which abet corruption. This review must also extend to the place of family, clan, community and tribe in the heart of every Nigerian.
\end{abstract}

Key words: Corruption; Culture; Analysis; Deprave, Experience

\section{Introduction}

Nigeria booms with many cultural groups. Within the traditions of these cultures are elements that abet the development and spread of 
corruption. Worrisome is that these cultural systems paint these unwholesome elements as normal, permissible and praiseworthy, thereby encouraging success by all means. Their influences on individuals have resulted to mass corruption, which is enormously felt in every other human structures or institutions. The culprits of corrupt practices are also influenced by other cultural orientations. For people in the modern world has evidently shown behaviours traceable to other cultures imbibed by association. The point however remains that human behaviours stem from culture as their primary source and strong base. This is why Gadamar (1967) asserts that nobody speaks or acts from nowhere but from cultural backgrounds. In this sense, our cultural orientations come to bear even in our gestures, and people see and interpret realities from cultural windows which shape their various existence.

Observably, explicit and tacit assumptions are central in human existence (Ugwu, 2012). One of such assumptions is the repudiation of the centrality of culture in mental and physical activities. As such, some scholars think that culture no longer play prominent inextricable role in human existence (Chinweuba \& Ezeugwu, 2016). Yet, in our active empirical activities, aspects of culture come to bear, fashioning and shaping all our inclinations, words, judgments, decisions and actions. In this vein, a critical examination of corrupt practices gives understanding that culture is the basis of the corrupt activities inherent in social, political, economic, religious, and philosophical modes and organization of human persons (Asiwaju, 1997).

Corruption is a social problem driving poverty, joblessness, inequality, low education skills, agitation, terrorism and conflict. It arises from the conflict of some obnoxious ideals of culture and pleasant national values. At this point, the individuals within the state tend to lack the moral will to resist cultural demands at the 
face of attractive and rewarding temptations. The moral will weakens further as it revolves on norms, values, ethos, mores, etc inculcated from cultural traditions. Hence, the will as well as other factors that lure people to corruption are generally informed by cultural experiences.

\section{Essence of Culture and Corruption}

Culture encapsulates norms, rules of behaviour, beliefs and practices. Bamikole (2008) concurs that it also underlies the contents of human associations and social movements. These are the rationale behind the definition of culture by Ogbu (1983, p. 38) as "a unified picture of the cosmos, explained by a system of concepts, which order the natural and social rhythms and the place of individuals in them". As such, culture manifests concretely in people's life making human actions and behaviours reflections of cultural experiences. Indeed, culture is a learnt phenomenon that in every space and time visibly forms human identity and shapes his inclination, assumption, attitude, character, belief and orientation from the cradle to the grave.

As Kanu (2010) observes, the progenitors actively thought it, coined it, and inculcated them in the a priori faculties of their kinsfolk, thereby making it part of the interiority of the human person. As such, Man, as Udebunu (2011) concurs does not operate in a vacuum, but from cultural structure which informs his uniqueness, values, likes and dislikes as he journey through the length and breadth of the universe.

Corruption however points at impairing integrity, virtue and moral principle. It is the state of being debase, deprave, deviant and improbity in decision making. Transparency International (2006) defines corruption as the abuse of entrusted 
power for private gain. Anand (2003, p. 3) adds that it is "the misuse of authority for personal, subunit, and/or organizational gain". Based on these, corruption encompasses commercial and private obnoxious practices like bribery, theft, embezzlement, extortion, favouritism, fraud, nepotism, etc which in all ramifications are at the expense of public interest. As a phenomenon that does not exist on a vacuum, there is a direct link between corruption and culture. For values and modes of life permissible in culture pervasively determine, guide and justify human social behaviours, and are also influentially central in human decision making in both private and public life. Hence, Pillay and Dorasanry (2010) contend that culture is generally an important macro variable that influences the perception and practices of corruption, which subverts public good and upholds private interests, thereby distorting societal development.

\section{Evolution of Corruption in Nigerian Cultures}

Every culture has a deprave side. This is as negativity and positivity are two existent opposing realities in human existence. But corruption gained exacerbation in Nigerian cultures with the advent of colonialism and imperialism. For social vices before colonial incursions in Nigerian cultures were initially very minimal. The colonizers in their desperation to subdue and dominate negatively tampered the indigenous cultures. This is the root of the disastrous consequences manifesting in corrupt practices that pervade the modern Nigerian society. Of course, the British cultural incursion in Nigeria was in direct adherence to the adopted proposal of Lord Macaulay (1835) by the British parliament. This proposal anchors on breaking the very backbone of the colonized by destroying their spiritual and cultural heritage, 
and replacing them with that of the British, which along the line ensures that the colonized upholds English culture and civilization to the repudiation of their heritage.

Thus, to subdue and exploit, the colonizers pushed Nigerians out of their historical, technical and socio-cultural current. First was the introduction of English language to drive English culture and civilization filled with reckless capitalism and other social ills into the natives. This was followed by rampaging missionaries who succeeded in distorting the autochthonous nature of Nigerian socio-religious cultures, which according to Kouassi (2016) were outstanding with strict moral codes.

Then came the British indirect rule system which according to Achebe (1993) enthroned 'upstarts and ruffians', as mushroom kings and Chiefs. This constituted cultural bankruptcy as these colonial representatives uphold the exploitative colonial and personal interests at the expense of the public good. This consequently thwarted what was left of the morality in Nigerian cultures, and created a foothold for the current inauthenticity, identity crisis and corrupt practices of Nigerians. From this new structure; consisting of the feeble remains of Nigerian indigenous cultural heritage and active colonial cultural structure evolved the current high corrupt practices, which also centers on maldistribution and uses of power to protect numerous dependants. The indigenous and colonial cultural collision therefore exacerbated corruption, which today permeates modern Nigeria society, developing a strong hold on the nation's political leaders, bureaucrats and even the ordinary citizens. 


\section{Cultural basis of corruption in Nigeria}

A critical study of corruption therefore reveals the cultural root. From this fulcrum, corruption further affected all the social institutions existent in Nigeria. It therefore stands that elements in most Nigerian cultures aggravated by colonial system favour the development and spread of corruption. The situation however became more exacerbated with the current globalization, secularism, modernism and humanism which made interaction with other cultures possible and fast. Take for instance, the customary exchange of gifts prevalent in most Nigerian cultures. This practice degenerates to bribery and favouritism. Though, the practice is explained as gratitude for favours received. It is also interpreted in terms of appreciation of one's personality or portfolio filled with anticipatory undertone. Factually, such gifts weaken the moral character of the recipient, and form an influence around his activities to the benefit of the giver.

Thus, the traditional 'exchange of gifts' and 'recognition' prevalent in most Nigerian cultures expose the thin line, create a sharp link between 'appreciation and anticipation' and convey an undue advantage on the giver, which eventually leads to corruption. Gyekye (1997) acknowledges this causal factor inherent in culture and states:

It would also be correct that gifts are offered in anticipation for an act of kindness by the recipient to the giver, or in anticipation of some reciprocities from the recipient (i.e. public official) in the form of favours. Gifts can thus insidiously corrupt a public official. It may therefore be said that the traditional practice of giving gifts to elders, or to public officials and "big men" and "big women" in government in the modern political setup is the causal factor in political corruption. 
In line with this assertion, Ani (2009) holds that in most Nigerian cultural traditions, appreciations are often made before or at every important transaction. Hence, people at the community, family and individual levels send gifts, congratulatory messages, felicitations, etc with anticipative undertones to stakeholders, public office holders, political appointees, etc mostly via the mass media. With the institutionalization of 'give and take' in most Nigerian cultural traditions therefore came corruption. Supporting this idea, Ani (2009) again posits that this practice has a different meaning and moral import within the family and communal system of obligations and reciprocities. Here, individuals have access to resources through reciprocity and obligation practices long embedded in family, lineage and community. This seems to provide a cultural under-pinning to contemporary corruption and makes the question of a 'culture of corruption' even more urgent.

In the Igbo culture of Nigeria specifically, wealth is not only praised but given important cultural eschatological implication. Against this backdrop, Oguejiofor (2004) states that no one who dies poor (enwe nta enwe imo-the miserable poor) deserves a place among the ancestors. Cultural elements like this also stand as a drive towards senseless pursuit of wealth and perpetration of corruption. With this plundering attitude inculcated from culture, most Nigerians now only care about returning home a wealthy person or sustaining their economic status at all cost. It therefore stands that some cultural systems are indeed explanatory factors, and major influences in the frequent incidence of corruption in Nigeria.

Truly, the cultural basis of corruption in Nigeria cannot be over emphasized. The family and community pressure on a public office holder of course gear towards nepotism, tribalism and embezzlement of public funds. These pressures are in expectations 
of 'cash and kind allegiance' demanded by the community, whose fulfillment makes one a true son or daughter. Like other cultures in Nigeria, Igbo communities are laden with cultural demands and obligations which are expected to be shown to the family, lineage, community, and ethnic group members during one's public service. Manifestations of these demands are indeed what Nigerians popularly describe as 'prospects of social connection'.

In line with these cultural conditions, De Maria (2001) reveals that to help a relation get admission when her marks are below the cut off is expected and morally justified, going by the rules of kinship, community and reciprocity, which applies when the stakes are personal and communual. Hence, the relationship of most Nigerians to the state highly depends on measurable material gain, which must be gotten by every hook or crook. Ekeh (1975) consequently observes that in this corrupt scenario, duties are deemphasized while rights are squeezed out of the civic public with the amorality of an artful dodger. As in every Nigerian affair, similar scenario even played out in the 2014 national conference in which Obatala (2014) concurs that the conferees publicly came up with individual clear cut agenda, which in most instances reflected ethnic or regional interests.

Thus, Nigerians armed with their cultural orientations, bend over backwards for whatever benefit or gain from the civic society to sustain their primordial origins. It is based on this reality, that government and public service are viewed as no man's business, or a distant entity whose allegiance should be subverted to cultural loyalty. As such, fraud, embezzlement, robbery and all kinds of corruption within it are illegitimately tolerated; so far they are directed at government treasuries and properties and not against the culprits' cultural society. To this end, Ani (2009) adds that public service is viewed as an alien institution and people's 
business was to go and get as much as possible from it as they could without getting into trouble, and to bring this loot back successfully to the family, clan, village or tribe-the object of African's allegiance and attachment (the 'getting into trouble' is thus seen as the only evil involved).

Based on these, it therefore stands that it is the socio-cultural systems inherent in Nigeria that drives the individual to corrupt practices. And should one undergo trial on account of corruption, his cultural group often stands by him, and mount pressures for his acquittal. In reality, corrupt personnel in Nigeria are often received with funfair and chieftaincy titles within their cultures. Explaining further the cultural foundation of corruption, Gyekye (1997) concurs that:

In the extended family system of African societies, an individual bears a dual responsibility: for himself and for the members of the group. These responsibilities are naturally onerous. To be able to shoulder them successfully requires an adequate personal economic position. An individual public official who has access to public resources may, in the process of striving to achieve that adequate economic position, take advantage of his official status and commits acts of official corruption. Second, the extended family system with its web of relatives-far and near-gives rise to patronage: the public official is expected to find jobs for some members of the extended family either in his organization or elsewhere. This often leads to nepotism, which is an act of corruption.

With the chronological growth of corruption stemming from Nigeria cultures, the effect has been disastrous. Ukwuaba (2002) 
submits that based on the current corrupt condition, public funds are being squandered to the enrichment of corrupt individuals. This paves way for the present massive unemployment and hunger in the country. Amidst these, foreign debts are being incurred, and governments at all levels are currently unable to pay salaries and pensions. In fact, public and social services in Nigeria at the moment are collapsing. This is coupled with abandoning of public projects, which in accordance with Dieg and Theobald (2000) gives rise to harsh living conditions and untimely death of some citizens. Conversely, greater numbers of the citizenry has learnt to curb every luxury and are reclining to austerity of life. But with the systematic deteriorating socio-political and economic structures, sustainable development is currently hindered. Consequently, there are agitations and hate speeches over-heating the polity, and resulting to national crisis and instability.

\section{The Nigerian Situation}

Corruption has evidently domiciled in Nigeria with no sign of leaving, plaguing every aspect of our national life. Ani (1999) observes that in 1997 and 2000, Transparency International ranked Nigeria the most corrupt country in the world. This is as corruption has affected the grassroots involving ordinary vendors, peasants, street hawkers, and small business owners who corrupt public officials and other bureaucrats, compromising them from performing their lawful duties. With this climax in corrupt practices, the former British Prime Minister, David Cameron (2016) described Nigeria as 'fantastically corrupt'. Decrying the Nigerian situation, Clark (1995) writes that Nigeria is beyond doubt the most corrupt nation in the world, where international fraud has reached epidemic proportions, and there is no sign of it 
abating. The foregoing thus shows that corruption has become prevalently endemic in Nigeria. But for the fact that not all Nigerians are corrupt, scholars have hesitated to view the problem as innate.

Meanwhile, scholars like Obi-Okogbue (2000) attributed the root cause of corruption in Nigeria to poverty. Yet, this origin does not address properly the high amount of corruption even in Nigerian first republic and during the oil boom when the economy was good. Notably, it was corruption that led to the first military coup d'état in Nigeria. The claim does not also address the fact that currently, not all poor Nigerians are corrupt. Based on these realities, the primordial cause of corruption in Nigeria cannot be correctly attributed to poverty. Poverty is rather the effect of corrupt practices. On a similar note, Hobbes (1985) argues that corruption rises from human nature with its severe egoistic drive. This theory also fails to explain the peculiar endemic nature of corruption in Nigeria than in other nations. It could not also explain the presence of some incorruptible Nigerians who also belong to the class of humans.

A critical look at corruption however reveals the weak moral character of Nigerians as its prime cause. For the moral character of an individual builds fundamentally from beliefs, moral laws, values, ideals, etc provided by human cultural traditions. These cultural elements based on their nature strengthen or weaken human will and character. Consequently, corruption fundamentally arises from culture. Worst still, most cultural traditions domiciled in Nigeria even abet and institutionalize corruption by endorsing the mere presence of wealth. Evidently, these cultures acknowledge, respect, appreciate and reward wealthy individuals irrespective of the dubious origins and ugly circumstances underlining their riches. In these cultures, societal authority has 
also shifted from the elderly and disciplined young people whose noble deeds guaranteed them as cultural models to whoever has lots of money. Even the revered traditional titles and leadership positions have gone the same way too. Ani (1999) recounts that:

In the typical Igbo meeting of umunna, the opinion of a penniless old man will certainly carry less weight in the light of the opinion of a wealthy young man, because, among many other immediate considerations, this is the same person who is capable of implementing projects concluded in the meeting. On a more immediate level, he will provide refreshments for the meeting, and any or everybody will always habour some hope of benefiting something from him. The question of the origin of one's wealth or his business identity is relegated to the background in the face of all the prospects of associating with him.

Cultural traditions in Nigeria have therefore been confronted, undermined and transformed with emphasis on riches by most cultural groups. Corrupt culprits regardless of their wealth identities are often recognized with traditional and religious titles. This correspondingly reflects on the national life where possessors of lots of money irrespective of their dubious sources are often recognized as stakeholders with national titles, honours, and portfolios. With 'money power', they are often 'above the law' to the amazement of the people. Sequel to this, Nigeria has today become a society where financial prowess with little or no morality is the standard.

Evidently, the Nigerian situation faults the functionality of Socratic equation of 'knowing and doing'. In his philosophical reflections, Socrates posits that people indulge in wrong deeds 
based on their lack of knowledge of such deeds. But, the Nigerian question proves that people can have full knowledge of moral principles, but slack in their commitment to such rules due to weakness of their will in the face of cultural pressure and alluring temptations. Hence an orientation gearing towards a change in attitude and strengthening of the will to a more commitment to moral rules is indispensable in curbing corruption in Nigeria.

\section{Panacea to Prevalent Corrupt Practices in Nigeria}

Based on the current situation, many scholars tend to anchor on the understanding that corruption has come to stay in Nigeria. But far from this, it is possible to eradicate corruption from Nigerian fabric. This eradication is more possible because corruption has a cultural basis since it results from cultural experience but afflicts members of the society and possesses no positive value. As such, a revolution in culture will lead to positive change in human society, and more so, reduction in corrupt practices. After all, culture was encountered by some past generation. This encounter undermined the existent tradition and evolved the inherent corrupt cultural elements. This makes cultural tradition a phenomenon inherited and created by any generation. More so, this portends the fact that traditions can be changed in a gradual fashion. Outstanding among the means to corruption eradication therefore is casting an active change on those unfavourable aspects of culture. This solution must gear towards the review of socio-cultural origins of corruption, the place of culture, family, extended family, kindred, clan, community and tribe in the heart of every Nigerian.

In addition, moral revolution should be extended from the religious angle to the socio-cultural spheres. This is important because the moral weakness of the individual gives rise to 
corruption. But moral weakness and strength are underscored by cultural ideals, beliefs, values, norms and ethos. Consequently, a socio-cultural overhaul or revolution should amount to a revolution in these factors that influence human will. Based on this, Gyekye (1997) suggests:

People will have to be morally weaned from the influences of the commune-cultural loyalties that obscure and subvert devotion and commitment to the national political community. A new national political morality that considers it totally morally unacceptable to use one's official position to obtain jobs for members of the extended family will need to be put in place. In other words, a new conception of loyalty to the state, fashioned and underpinned by new moral values, will need to be created.

In line with this bid, Amujiri (1997) proposes:

Another method to be used in eliminating corruption is community-based strategy. Community-based strategy is rationalized on the basis that it is not the police and the law, which prevent crime, as Werner (1993) noted, it is the community. Community justice can liberate Nigeria from corruption. Since much of the money looted find their way to the rural communities where such corrupt official is honoured with chieftaincy title, we suggest the setting up of community tribunals to try such person(instead of honouring such person with chieftaincy title) within the community. The community-based strategy will greatly deter corruption in Nigeria because the offender cannot escape punishment from his own people. 
Indeed, these remedies should be followed with strengthening of socio-political, economic and legal institutions that sustain a corrupt free society. Public institutions in addition should be overhauled in such a way that they become unattractive and unrewarding to the culprits. Academic institutions should as well be overhauled to accommodate 'strength of moral will', character and national loyalty which ought to be reflected in the curriculum. Such orientation as held by Huntington (1981) is even obtainable in the educational system of the United States of America, where learners are taught the general American ideals. These ideals revolving around 'strength of moral will', sound mind and national loyalty, provide the basis for subsequent adult adherence to basic values of American social system, embedded in 'thinking of what to do for America first', 'making America great', and upholding a corrupt free society. The attitudes also form the basis for acceptance of the legitimacy of the socio-political system, economic system, and institutions that enhance human existence. Hence corruption in such societies is at the minimal level.

In this direction still, the mass media domiciled in Nigeria should be charged with the responsibility of public re-orientation, cultural reformation and improvement. This should be reflected in media programmes, agenda settings and entertainment. These programmes should be disseminated in indigenous languages to ensure the understanding of the majority of the citizenry, and to achieve the desired goal.

\section{Conclusion}

The discourse so far proves that a link exists between some cultural elements and corruption in Nigeria. Evidently, illegitimate 'give and take' syndrome, bribery and corruption prevalent in 
Nigeria have grown chronologically from this nexus. In fact, it is for the well being of the individual and the community that people come to steal from the public coffer. Unfortunately, such unwholesome behaviours are normal in many cultures as part of the survival system. This confirms the fact that cultural matters are integral parts of the lives we lead, and efforts gearing toward development must not ignore the world of culture (Amartya, 2014). Until cultural elements that spread corruption are deemphasized in Nigerian cultural system, corruption of various levels will continue to thrive in Nigeria.

Gregory Emeka Chinweuba

Philosophy Unit,

General Studies Division

Enugu State University of

Science and Technology,

Enugu

\section{References}

Achebe, C. (1998). The Trouble with Nigeria, Enugu, Nigeria: Fourth Dimension Publishing.

Anand, B. E. (2003). The Normalization of Corruption in Organization. Research in Organizational Behaviours. 152.

Amartya, S. (2014). Culture and Development, World Bank Meetings. http://info.worldbank.org 13/12/2014.

Amujiri, B. A., Bureaucratic Corruption in Enugu State Civil Service and the Development of the State: An 


\section{Assessment", A PhD Seminar Paper Presented to PALG, UNN, 1997.}

Ani, E. I. (2009). Corruption and Culture in Nigeria: Between Institutionalism and Moral Individualism. Uche Journal of the Department of Philosophy, 15, 67-88.

Asiwaju, A. I. (1997). The Evolution of Culture. In A. Osuntokun \& A. Olukoju (Ed.), Nigerian Peoples and Culture, (pp. 2242). Ibadan, Nigeria: Davidson Press.

Bamikole, L. O. (2008). Democracy in a Multicultural Society. Philosophy and Praxis, 4, 1-20.

Chinweuba, G. E., \& Ezeugwu, E. C. (2016). Thinking and Culture: A Philosophical Analysis. International Journal of Innovation Research and Advanced Studies, 3, 90-93.

De Maria, W. (2005). Does African Corruption Exist? Pretoria, South Africa: Preton.

Dieg, A., and Theobald, R. (2000). Corruption and Democracy. London, England: Frank Cass.

Ekeh, P. (1975). Colonialism and the Two Publics in Africa: A Theoretical Statement. Comparative Studies in Society and History, 17, 1-9.

Gadamer, H. G. (1967). Kleine Schriften 1. Tubingen, Germany: J. C. B. Mohr.

Gyekye, K. (1997). Tradition and Modernity: Philosophical Reflections on the African Experience. Oxford, England: Oxford University Press.

Hobbes, T. (1985). Leviathan. London, England: Penguin Books. Huntington, S. P. (1981). American Politics the Promise of Disharmony. Massachusetts, USA: Harvard University Press. 
Kanu, A. I. (2010). Towards an African Cultural Renaissance. Professor Bassey Andah Journal of Cultural Studies. 3, 147-155.

Kalu, O. (1983). African Cultural Development. Enugu, Nigeria: Fourth Dimension Publishers.

Kouassi, C. N. (2016). Modern Nigeria and the Roots of Corruption: A Historico-Philosophical Reflection. Journal of Philosophy, Culture and Religion. 17, 6-11.

Lord Thomas Babington Macaulay's Brief Address to the British Parliament on $2^{\text {nd }}$ February, 1835. historum.com/asian history/26268-lo...10/05/2017.

Obatala, J. K. (2014, July 13). Nigeria will gain nothing from Confab, says Tomori. The Guardian.

Obi-Okogbuo, J. (2000). The History and Aetiology of Corruption in Nigeria: A Critical Appraisal. In W. S. Tile (ed.), Towards a Corrupt Free Democratic Society, (pp. 15- 34). Enugu, Nigeria: Vougasen Ltd., 2000.

Ogbu, U. K. (1975). Tradition in Revolutionary Change. Ikenga Journal of African Studies, Institute of African Studies, University of Nigeria, Nsukka. 3, 53-58.

Oguejiofor, O. J. (2004). African Philosophy and the Function of Socio-political Criticism; A Skeptical Consideration. Uche Journal of the Department of Philosophy, 10, 23-39.

Pillay, S., and Dorasanry, N. (2010). Linking Cultural Dimensions with the Nature of Corruption: An Institutional Theory Perspective. International Journal of Cross Cultural Management. 10, 363-378.

Transparency International (2006). http://www.transparency.org 28/07/2017.

Udebunu, C. (2011). Nigeria and Dialectics of Multiculturalism. Ogirisi A New Journal of African Studies. 8, 1-15. 
Ugwu, E.C. (2012). Culture, Human Resource Management and Local Council Administration in Nigeria: A study of Local Government Areas in Enugu State. Ikoro: Journal of Institute of African Studies. 9, 132-162.

Ukwuaba, I. (2002). Political Corruption in Nigeria: An Assessment of the First, Second and Fourth Republics. In C. O. T. Ugwu (ed.), Corruption in Nigeria: Critical Perspectives: A Handbook of Readings, (pp. 14-25). Nsukka: Chuka Educational Publishers.

Werner, S. B. (1993). New Directions in the Study of Administrative Corruption. London, UK: Edward Bglar Press Ltd. 